\title{
Elimination Behaviors of NOx in the Sintering Process with Flue Gas Recirculation
}

\author{
Xiaohui FAN, Zhiyuan YU, ${ }^{*}$ Min GAN, Xuling CHEN, Qiang CHEN, Shu LIU and Yunsong HUANG \\ School of Minerals Processing \& Bioengineering, Central South University, Changsha, Hunan, 410083 P. R. China. \\ (Received on March 27, 2015; accepted on June 10, 2015)
}

\begin{abstract}
A novel sintering process is proposed based on part of flue gas is reused by reintroducing the flue gas into sintering bed, which is of great significance to cleaner production of sinter because it can reduce significantly the emission of exhaust gas. The reaction behaviors of NOx during flue gas recirculation (FGR) process are researched. The elimination behavior of $\mathrm{NOx}$ in sinter zone is $\mathrm{NO}-\mathrm{CO}$ reaction on the catalysis of sinter, and the degradation rate of $\mathrm{NOx}$ reaches a maximum at $700^{\circ} \mathrm{C}$. The $\mathrm{NOx}$ formation supervenes with coke combustion in combustion zone. The NOx formation decreases due to the significantly reduced $\mathrm{O}_{2}$, increased $\mathrm{CO}_{2}$, and increased $\mathrm{NO}$ of FGR gas. The combustion atmosphere is the key point on the $\mathrm{NOx}$ elimination since the fuel-N decomposition intermediate products could transform to NO or reduce $\mathrm{NO}$. Moreover, the NO-carbon reaction conducting in combustion zone contributes to the NOx elimination further. Therefore, it can significantly reduce the NOx emission of sintering process when the FGR technology is taken in the sintering process.
\end{abstract}

KEY WORDS: iron ore sintering; flue gas recirculation; sinter zone; combustion zone; reaction behavior.

\section{Introduction}

Reducing NOx (mainly including $\mathrm{NO}$ and $\mathrm{NO}_{2}$ ) emissions is of global interest due to the NOx adverse effects on the environment and human health. ${ }^{1)}$ NOx can combine with VOCs to form ground-level ozone, particulate matter, and ultimately be oxidized to form $\mathrm{NO}^{3-}$. Excess $\mathrm{NO}^{3-}$ is a key factor in environmental and ecological problems, like acidic deposition, degradation of drinking water etc. Anthropogenic NOx emissions have greatly increased primarily due to increased fossil fuel combustion and vehicles in the Industrial Revolution. ${ }^{2,3)}$ The NOx emissions from iron and steel industry approximately account for $6 \%$ of the total industrial emissions in China. Meanwhile, NOx emissions from the sintering machine represent about $48 \%$ of all emission from iron and steel industry. ${ }^{4,5}$ Thus it is very essential to reduce NOx emissions from the sintering machine, which contributes to the cleaner production of sinter.

Recent and ongoing efforts aim at further reducing ambient NOx concentrations globally, which mainly includes source control, process control and end of pipe technology. ${ }^{6}$ ) Cho Guk Jin et al. research how to reduce NOx emission in the source by using low nitrogen of coke in the sintering process $;^{7)}$ the process control technology is generally described as adding some additives into the sintering mixture to inhibit NOx generation, such as carbohydrate, ${ }^{8)} \mathrm{Ca}-$ Fe oxides, ${ }^{9)}$ ammonia ${ }^{10)}$ and modified coke. ${ }^{11)}$ The efficiency of source and process control is relatively lower since the species and amount of low nitrogen fuels and additives are

\footnotetext{
* Corresponding author: E-mail: y13975104962@126.com DOI: http://dx.doi.org/10.2355/isijinternational.ISIJINT-2015-180
}

few choices. The end of pipe technologies including flue gas denitration and flue gas recirculation develop rapidly in recent years. Flue gas denitration is divided into three categories, like wet denox process, semi-dry denox process and dry denox process. The dry denox process dominates in the flue gas denitration technology since its efficiency is the highest, which can reach $80 \%-90 \%{ }^{12,13)}$ Due to the high gas flow rate and low NOx concentration, it suffers high cost of investment/operation and low utilization of byproducts. Therefore, the flue gas recirculation technology is proposed by the researchers aiming to reducing the exhaust gas emission and reusing waste heat in 20th century, which is developed based on a principle that parts of waste gases recycled into sintering bed. The application of flue gas recirculation in sintering process lead to a significant decrease in the emissions of pollutants, like producing 1 ton sinter will reduce $35 \%-45 \%$ dust, $20 \%-45 \%$ NOx, $60 \%-70 \%$ dioxin, $25 \%-30 \% \mathrm{SO}_{2}$ and $40 \%-50 \% \mathrm{CO}$. In addition, the reuse of waste heat in circulating flue gas is favorable to reduce solid fuel consumption of 2-5 kg/t-sinter. ${ }^{14-17)}$

However, the NOx content of exhaust gas increases even though $20 \%-45 \%$ reductions in NOx emissions in the case of FGR technology. The NOx content in stack should be reduced to comply with the more and more stringent environmental regulations. Our researches attempt to reveal the reaction behavior of NOx in sintering bed during the FGR process which is simulated by five zones defined based on the temperature and physical and chemical reactions, and then propose the mechanism or operating parameters that makes a contribution to further reduction in the NOx content of exhaust gas in FGR sintering. 
Table 1. Chemical composition of raw materials and their percents in mixture $/ \operatorname{mass} \%$

\begin{tabular}{lrrrrrrrr}
\hline Raw materials & $\mathrm{TFe}$ & $\mathrm{SiO}_{2}$ & $\mathrm{CaO}$ & $\mathrm{MgO}$ & $\mathrm{Al}_{2} \mathrm{O}_{3}$ & $\mathrm{FeO}$ & LOI & Ratio \\
\hline Iron ore fine & 60.01 & 4.39 & 2.84 & 0.61 & 1.37 & 4.59 & 5.16 & 58.96 \\
dolomite & 0.32 & 0.41 & 31.66 & 21.38 & 0.01 & 0.06 & 45.56 & 2.48 \\
limestone & 0.22 & 0.88 & 55.21 & 0.25 & 0.24 & 0.06 & 42.88 & 3.16 \\
burnt lime & 0.30 & 3.61 & 69.3 & 1.33 & 0.68 & 0.06 & 24.39 & 1.50 \\
Coke breeze & 0.85 & 7.40 & 0.59 & 0.11 & 1.49 & 0.00 & 87.30 & 3.90 \\
Return fine & 57.06 & 5.14 & 9.47 & 1.84 & 1.70 & 6.64 & 0.77 & 30.00 \\
\hline
\end{tabular}

Table 2. Proximate analysis and elemental analysis of coke breeze/ $\operatorname{mass} \%$.

\begin{tabular}{cccc|ccc}
\hline Fuel & Ad & Vdaf & FCad & S & N & H \\
\hline Coke breeze & 14.36 & 2.92 & 82.72 & 0.78 & 0.72 & 0.33 \\
\hline
\end{tabular}

* Ad: ash content (dry basis); Vdaf: volatile matter content (dry ash-free basis); FCad: fixed carbon content (air dried basis).

\section{Materials and Methods}

\subsection{Sintering Pot Test}

\subsubsection{Raw Material}

Iron ore blending, fuels and fluxes (including dolomite, limestone, quicklime) were utilized to produce sinter with TFe 58.11\%, $\mathrm{SiO}_{2} 4.88 \%$, basicity $\left(\mathrm{R}=\mathrm{CaO} / \mathrm{SiO}_{2}\right) 1.85$ and $\mathrm{MgO} 1.60 \%$. The chemical compositions of raw materials and their mass fractions are given in Table 1. The proximate analysis of coke breeze and chemical composition of its ash are shown in Table 2. The fixed carbon content was $82.72 \%$ while the nitrogen content was $0.72 \%$.

\subsubsection{Pot Tests Apparatus}

The sintering tests were conducted in a laboratorial pot which was $100 \mathrm{~mm}$ in diameter and $700 \mathrm{~mm}$ in height. The schematic diagram of the sintering apparatus was shown in Fig. 1. Sintering tests include ore proportioning, mixing, granulation, ignition, sintering, cooling, sieving and quality testing of sinter. The operation methods were as below: The raw materials were mixed after ore proportioning. Then the mixture was charged into a drum mixer of $600 \mathrm{~mm}$ in diameter and $300 \mathrm{~mm}$ in length to granulate for $4 \mathrm{~min}$ at 15 $\mathrm{r} / \mathrm{min}$. The granulated mixture was then fed into the sintering pot after $0.5 \mathrm{~kg}$ sinters of $10-16 \mathrm{~mm}$ fed on the grate bars. The mixture was ignited with nature gas for $1.5 \mathrm{~min}$ at $1050^{\circ} \mathrm{C}$ at the top of pot under the suction pressure of 5 $\mathrm{kPa}$, and then kept heating at $950^{\circ} \mathrm{C}$ for $1 \mathrm{~min}$. The mixture experienced a series of sintering reactions under an initial suction pressure of $10 \mathrm{kPa}$. Subsequently, cooling followed for $3 \mathrm{~min}$ at $5 \mathrm{kPa}$ suction pressure. After sintering, the sinter indexes were measured and calculated, including VSV (vertical sintering velocity), $P$ (productivity), $Y$ (yield) and $T I$ (tumble index). The sintering time was the total time from the ignition to the BTP (burn through point). The $V S V$ was calculated by dividing initial height of sintering bed by sintering time. The $Y$ stated the qualified rate of sinter, which was defined as the mass fraction of particles of $>5$ mm size. It was detected by the standard of JIS M87111977. The $P$ was defined as the sinter production of per unit time and area, which revealed the production efficiency of

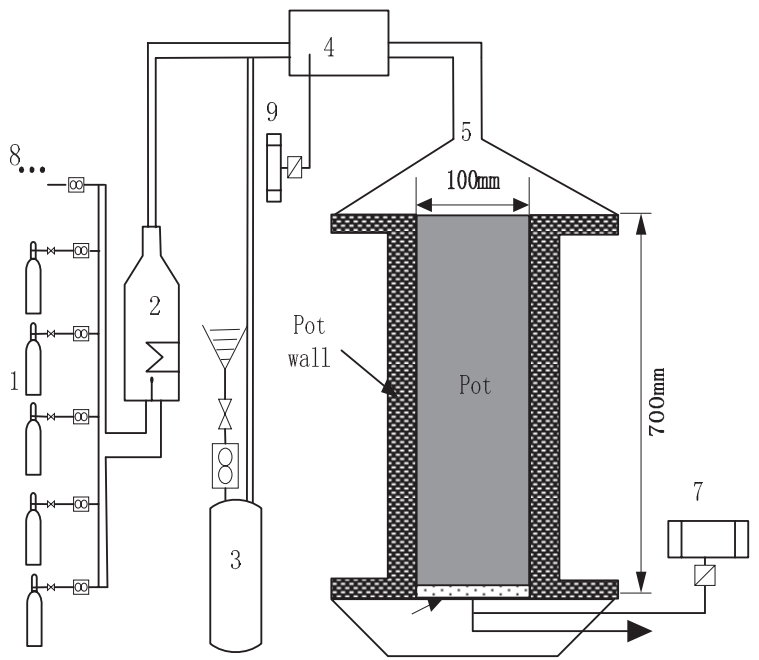

1-standard gas 2-shaft furnace 3-steam production 4-gas mixing room 5-sealer cover 6-hearth layer 7,9-flue gas analyzer 8-air gas

Fig. 1. Simulation of sintering process with flue gas recirculation.

sintering machine. The $T I$ was measured according to the standard of ISO 3271-1975.

For simulating the process of FGR, a sealed cover was added on the top of sintering pot after igniting, and the circulating gas was introduced onto the surface of pot through the pipeline. The simulation system of FGR included gas blending system, steam generator and pre-heating furnace. The circulating flue gases pre-heated by the vertical furnace were simulated by mixing air and standard gases (including $\mathrm{O}_{2}, \mathrm{CO}, \mathrm{CO}_{2}, \mathrm{NO}$ and $\mathrm{Ar}$ ), and then joined with the steam to introduce into sintering bed. Moreover, the components and temperature of inlet gas were controlled by a gas analyzer. Besides, the compositions of flue gas were tested by another gas analytical instrument (MGA 5, MRU Corporation of Germany) during sintering process.

\subsubsection{Determination of Concentrations of Re-circulated Gases}

The components of circulating flue gas were calculated based on the principles that exhaust gas emission rule and mass balance. The principles included:

(1) $\mathrm{Q}_{\text {cir }}$ (gas required as using flue gas recirculation process $)$ was determined according to the equation $\left(\mathrm{C}_{\text {cir }} \cdot \mathrm{Q}_{\text {cir }}=\right.$ $\mathrm{Q}_{\text {air }} \cdot \mathrm{C}_{\mathrm{air}}$ ). $\mathrm{Q}_{\text {air }}$ (gas required as using conventional sintering process) was ascertained by tests while the $\mathrm{C}_{\mathrm{air}}$ (the heat capacity of air) and $\mathrm{C}_{\text {cir }}$ (the heat capacity of circulating flue gas) were known physical quantities which were related to the properties of gas. If the amount of circulating flue gas couldn't reach the $\mathrm{Q}_{\text {cir }}$, the short part is made up with hot cooling gas. (2) The consumption of $\mathrm{O}_{2}$ and production of $\mathrm{CO}_{2}$ and $\mathrm{H}_{2} \mathrm{O}(\mathrm{g})$ during FGR sintering were calculated according to carbon, $\mathrm{H}_{2} \mathrm{O}, \mathrm{FeO}$ and carbonate contents of sintering mixture. (3) The phenomenon that $\mathrm{CO}$ in inlet gas was combusted completely was assumed during FGR sintering process. The gas temperature is controlled by regulating the hot cooling gas if it is lower than $250^{\circ} \mathrm{C}$.

A multiple linear equation set is proposed and solved according to the principle that mentioned above, of which the solution presents the compositions and temperature of circulating flue gas under the conditions of different propor- 
Table 3. Properties of circulating flue gas of different technologies.

\begin{tabular}{|c|c|c|c|c|c|c|c|}
\hline \multirow{2}{*}{$\begin{array}{l}\text { Sintering } \\
\text { condition }\end{array}$} & \multirow{2}{*}{$\begin{array}{l}\text { Recirculation } \\
\text { ratio/vol\% }\end{array}$} & \multicolumn{5}{|c|}{$\begin{array}{l}\text { Circulating flue gas } \\
\text { composition/vol } \%\end{array}$} & \multirow{2}{*}{$\begin{array}{c}\text { Circulating } \\
\text { flue gas } \\
\text { - temperature } \\
{ }^{\circ} \mathrm{C}\end{array}$} \\
\hline & & $\mathrm{O}_{2}$ & $\mathrm{CO}_{2}$ & $\mathrm{CO}$ & $\mathrm{H}_{2} \mathrm{O}$ & NOx & \\
\hline Conventional & 0 & 21.00 & 0 & 0 & 0 & 0 & $\begin{array}{l}\text { Room } \\
\text { temperature }\end{array}$ \\
\hline \multirow{4}{*}{ FGR } & 20 & 18.42 & 1.74 & 0.19 & 2.40 & 0.0100 & \multirow{4}{*}{250} \\
\hline & 25 & 17.55 & 2.28 & 0.23 & 3.14 & 0.0180 & \\
\hline & 30 & 16.57 & 2.87 & 0.28 & 3.96 & 0.0256 & \\
\hline & 35 & 15.43 & 3.52 & 0.33 & 4.86 & 0.0345 & \\
\hline
\end{tabular}

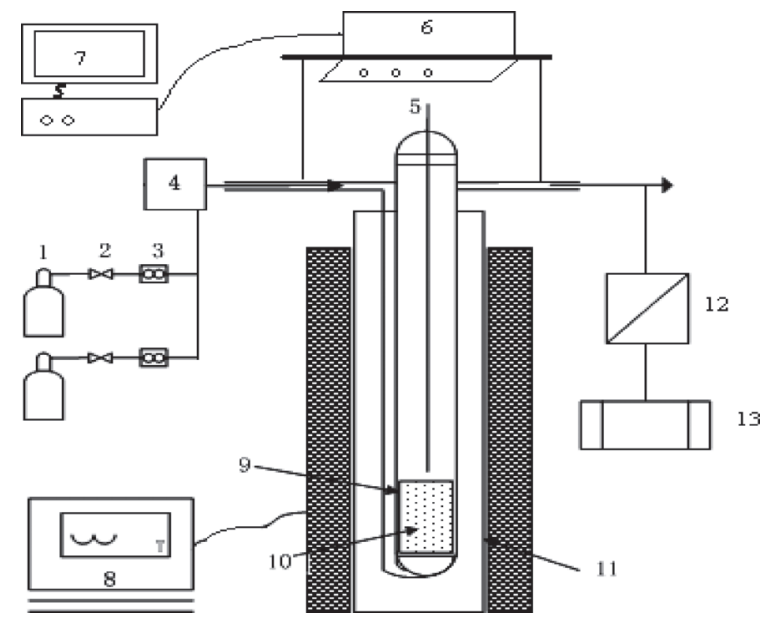

1-gas 2-valve 3-flowmeter 4-mixing box 5-thermalcouple 6-electronic balance 7-computer 8-temperature controller 9-quartz tube 10-charging cup 11-shaft furnace 12-dryer 13-gas analyzer

Fig. 2. Schematic diagram of sinter zone simulation.

tions. Table 3 shows the components and temperature of circulating flue gas.

Compared to conventional process, with the increase of FGR ratio, COx and steam contents were increased while $\mathrm{O}_{2}$ content was reduced. The $\mathrm{O}_{2}$ content was $15.43 \mathrm{vol} \%$ as well as the steam content was increased to $4.86 \mathrm{vol} \%$ when the FGR ratio was $35 \mathrm{vol} \%$. And the temperature of circulating flue gas increased from room temperature to $250^{\circ} \mathrm{C}$.

\subsection{Electric Furnace Test}

\subsubsection{Experimental Apparatus}

The sintering bed were divided five zones based on the temperature and physical and chemical reactions in order to simulate the sintering process, sinter zone, combustion zone, drying-preheating zone, over-wet zone and green mixture zone vertically. When flue gas was circulated to sintering bed, it passed through the five zones successively. In this paper, the reaction behaviors of NOx in circulating flue gas during the sintering process were mainly studied in sinter and combustion zones since NOx hardly got changed in the sub-layer. The reaction behaviors of NOx during the sinter zone and combustion zone were investigated in a quartz fixed bed reactor which was $10 \mathrm{~mm}$ in diameter and 50 $\mathrm{mm}$ in height, and the schematic diagram of the sintering apparatus was shown in Fig. 2. The experimental apparatus includes gas atmosphere simulation, heat pattern simulation and exhaust gas monitoring.

The experiments proceeded as follows: $40 \mathrm{~g}$ sinter (used to simulate sinter zone) or granulated mixture dried in advance (used to simulate combustion zone) of 5-8 $\mathrm{mm}$ were charged into the charging cup; the granulate mixture came from the granulation while the sinter sample was the final product of sinter pot test. When taking sinter zone simulation test, the sinter zone temperature $\left(500-900^{\circ} \mathrm{C}\right)$ was as the same as the set pre-heat temperature since no much heat released from sinter samples. However, as much heat released by coke combustion in combustion zone, the pre-heat temperature was set relatively lower than the maximum temperature of combustion zone. The temperatures of combustion zone $\left(1100-1300^{\circ} \mathrm{C}\right)$ were achieved by setting the pre-heat temperature according to the curve which is fitted based on a series of experiments on the relationship between temperature of sinter bed and setting temperature of electric furnace. At the same time, a special content standard gases $\left(\mathrm{O}_{2}, \mathrm{CO}, \mathrm{CO}_{2}, \mathrm{NO}\right.$ and $\left.\mathrm{Ar}\right)$ were introduced into the quartz tube and passed through the charging cup after mixing. And the gas velocity kept a constant at $18 \mathrm{~m} / \mathrm{min}$. The compositions in outlet gas were detected by gas analyzer along with the heating period. The gas analyzer named as MGA5 was intelligent infrared multigas analyzer. On the basis of NDIR technology, MGA5 can measure multigas such as $\mathrm{O}_{2}, \mathrm{CO}, \mathrm{CO}_{2}, \mathrm{NO}, \mathrm{NO}_{2}, \mathrm{NOx}, \mathrm{SO}_{2}$ and $\mathrm{CxHy}$.

\subsubsection{Experimental Conditions}

Unlike the conventional air condition, ${ }^{18)}$ the gas compositions of introducing gas were controlled according to the atmosphere conditions in Table 4, which was the simulation of sintering atmosphere in the case of FGR process. The temperature of sinter zone varied from 500 to $900^{\circ} \mathrm{C}$ with an atmosphere of $0.4 \% \mathrm{CO}, 16 \% \mathrm{O}_{2} 4 \% \mathrm{CO}_{2}$ and $345 \mathrm{ppm}$ $\mathrm{NO}$ when studying the influence of temperature factor on $\mathrm{NO}-\mathrm{CO}$ reaction; while the influence of $\mathrm{CO}$ content was revealed by changing its content with $16 \% \mathrm{O}_{2}, 4 \% \mathrm{CO}_{2}$ and $345 \mathrm{ppm} \mathrm{NO}$ under $700^{\circ} \mathrm{C}$. However, the factors on reaction behavior of $\mathrm{NO}$ in combustion zone covered temperature, $\mathrm{O}_{2}$ and $\left(\mathrm{O}_{2}+\mathrm{CO}_{2}\right)$ since the fuel combustion player a leading role in combustion zone, which is closely related to the NOx generation. The effect of combustion zone temperature on NOx generation with or without NOx was researched by varying the temperature from 1100 to $1300^{\circ} \mathrm{C}$. Another important factor on combustion zone was atmosphere, which performed as the changes of $\mathrm{O}_{2}$ and $\mathrm{CO}_{2}$ contents. Firstly just changed $\mathrm{O}_{2}$ content in the range of $25 \%-10 \%$ under $1300^{\circ} \mathrm{C}$, then adjusted the $\mathrm{CO}_{2}$ content from 0 to $11 \%$ under the precondition of $\left(\% \mathrm{O}_{2}+\% \mathrm{CO}_{2}=21 \%\right)$. All the rest of gas flow was made up with Ar.

\section{Results}

\subsection{Reaction Behavior of NO in Sinter Zone}

3.1.1. Effect of Sinter Temperature on NO-CO Reaction

Figure 3 shows the effect of sinter temperature on NO$\mathrm{CO}$ reaction in sinter zone. NOx content in outlet gas hardly changed when sinter temperature was $500^{\circ} \mathrm{C}$ or lower. While it significantly decreased in the range of $600^{\circ} \mathrm{C}$ to $700^{\circ} \mathrm{C}$. Moreover, NOx content in the outlet gas maintained the lowest level when the temperature was $700^{\circ} \mathrm{C}$. NOx 
Table 4. Experimental conditions of electric furnace tests.

\begin{tabular}{|c|c|c|c|c|c|c|c|}
\hline & Factors & $\underset{{ }^{\circ} \mathrm{C}}{\text { Temp. }}$ & $\mathrm{CO} / \%$ & $\mathrm{O}_{2} / \%$ & $\mathrm{CO}_{2} / \%$ & $\mathrm{NO} / \mathrm{ppm}$ & $\mathrm{Ar}$ \\
\hline \multirow{9}{*}{ Sinter zone } & \multirow{5}{*}{ Temp. } & 500 & 0.4 & 16 & 4 & 345 & Rest \\
\hline & & 600 & 0.4 & 16 & 4 & 345 & Rest \\
\hline & & 700 & 0.4 & 16 & 4 & 345 & Rest \\
\hline & & 800 & 0.4 & 16 & 4 & 345 & Rest \\
\hline & & 900 & 0.4 & 16 & 4 & 345 & Rest \\
\hline & \multirow{4}{*}{$\mathrm{CO}$} & 700 & 0 & 16 & 4 & 345 & Rest \\
\hline & & 700 & 0.4 & 16 & 4 & 345 & Rest \\
\hline & & 700 & 0.8 & 16 & 4 & 345 & Rest \\
\hline & & 700 & 1.2 & 16 & 4 & 345 & Rest \\
\hline \multirow{15}{*}{$\begin{array}{c}\text { Combustion } \\
\text { zone }\end{array}$} & \multirow{6}{*}{ Temp. } & 1100 & 0 & 21 & 0 & 0 & Rest \\
\hline & & 1200 & 0 & 21 & 0 & 0 & Rest \\
\hline & & 1300 & 0 & 21 & 0 & 0 & Rest \\
\hline & & 1100 & 0 & 21 & 0 & 345 & Rest \\
\hline & & 1200 & 0 & 21 & 0 & 345 & Rest \\
\hline & & 1300 & 0 & 21 & 0 & 345 & Rest \\
\hline & \multirow{5}{*}{$\mathrm{O}_{2}$} & 1300 & 0 & 25 & 0 & 0 & Rest \\
\hline & & 1300 & 0 & 21 & 0 & 0 & Rest \\
\hline & & 1300 & 0 & 17 & 0 & 0 & Rest \\
\hline & & 1300 & 0 & 13 & 0 & 0 & Rest \\
\hline & & 1300 & 0 & 10 & 0 & 0 & Rest \\
\hline & \multirow{4}{*}{$\mathrm{O}_{2}+\mathrm{CO}_{2}$} & 1300 & 0 & 21 & 0 & 0 & Rest \\
\hline & & 1300 & 0 & 17 & 4 & 0 & Rest \\
\hline & & 1300 & 0 & 13 & 8 & 0 & Rest \\
\hline & & 1300 & 0 & 10 & 11 & 0 & Rest \\
\hline
\end{tabular}

Temp.*: temperature.

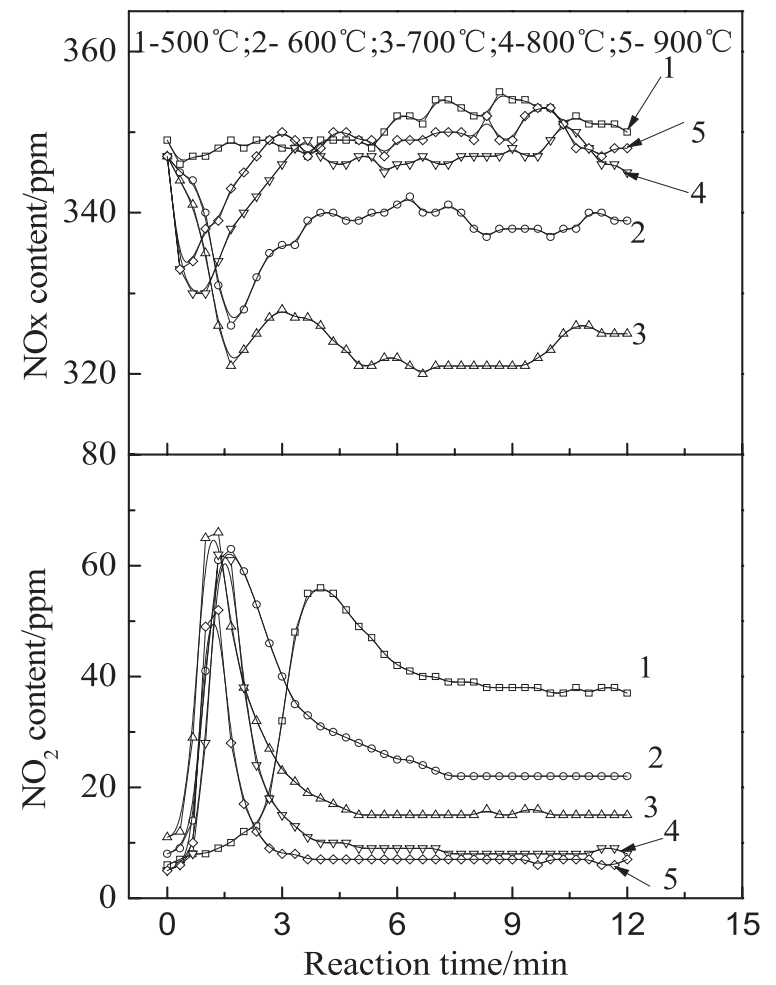

Fig. 3. Influence of sinter temperature on reaction behavior of NOx in sinter zone.

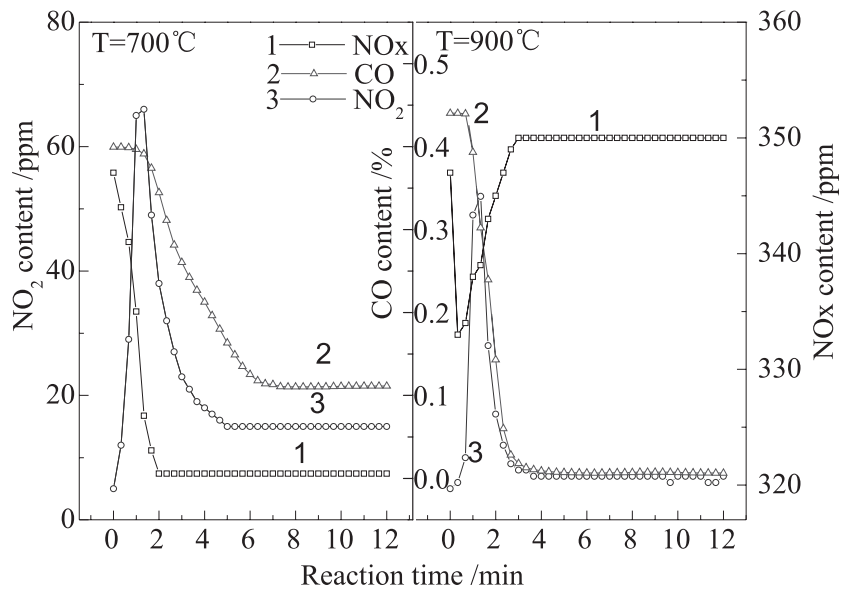

Fig. 4. Relationship of CO and NOx in sinter zone under different temperature.

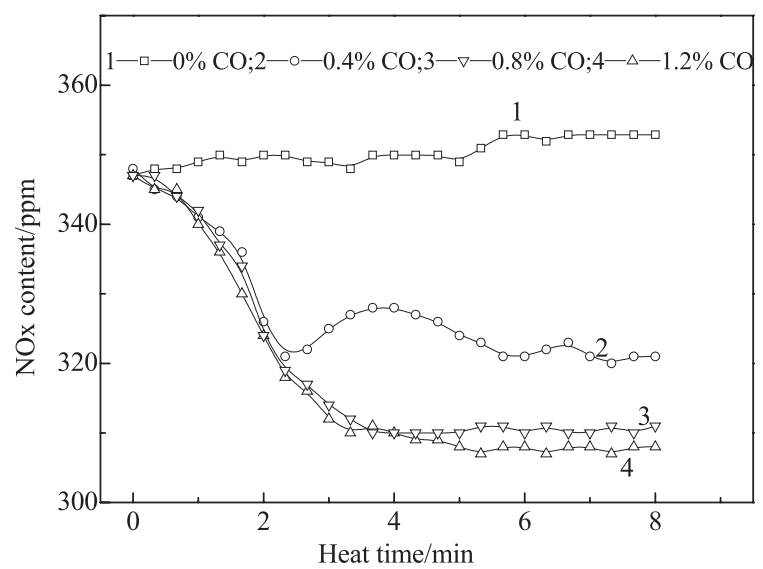

Fig. 5. Influence of $\mathrm{CO}$ content on reaction behavior of $\mathrm{NO}$ in sinter zone.

content in the outlet gas decreased in initial phase and then increased to the same content in circulating flue gas when the sinter temperature continued to rise to $800-900^{\circ} \mathrm{C}$. In a word, the $\mathrm{NO}-\mathrm{CO}$ reaction in sinter zone proceeded fastest at $700^{\circ} \mathrm{C}$. The $\mathrm{NO}$ oxidation to $\mathrm{NO}_{2}$ was easily found out; however, $\mathrm{NO}_{2}$ content in outlet gas was decreased after the first increase under a low temperature condition. And $\mathrm{NO}_{2}$ content in outlet gas decreased with the increase of temperature.

As the above study on sinter temperature, the reduction efficiency of $\mathrm{NO}$ was the most significant under $700^{\circ} \mathrm{C}$ while it was negligible except initial phase under $900^{\circ} \mathrm{C}$. Figure 4 shows the relationship of $\mathrm{CO}$ and NOx in sinter zone under $700^{\circ} \mathrm{C}$ and $900^{\circ} \mathrm{C}$. When the sinter temperature was $700^{\circ} \mathrm{C}, \mathrm{CO}$ and $\mathrm{NOx}$ contents in outlet gas were decreased along with the reaction time increasing. However, $\mathrm{CO}$ content in outlet gas decreased to null sharp while NOx content in outlet gas increased rapidly after the first decrease when the sinter temperature was $900^{\circ} \mathrm{C}$. At the same time, $\mathrm{NO}$ was easily oxidized to form $\mathrm{NO}_{2}$ in the existence of $\mathrm{O}_{2}$. $\mathrm{NO}_{2}$ content in outlet gas under $900^{\circ} \mathrm{C}$ was less than its under $700^{\circ} \mathrm{C}$ since $\mathrm{NO}$ oxidation was exothermic reaction.

\subsubsection{Effect of CO Content}

Figure 5 shows the effect of $\mathrm{CO}$ content in circulating 
flue gas on reaction behavior of NO in sinter zone when the sinter temperature was $700^{\circ} \mathrm{C}$. $\mathrm{NO}$ in circulating flue gas was reduced with the existence of $\mathrm{CO}$ under the catalysis of sinter in sinter zone. In addition, NO content in outlet gas was decreased with increasing of $\mathrm{CO}$ content in circulating flue gas. The degradation rate of NO was defined as $\left(\mathrm{NO}_{\text {inlet }}-\mathrm{NO}_{\text {outlet }}\right) / \mathrm{NO}_{\text {inlet }}$, which increased with the raise of $\mathrm{CO}$ content. While it was similar when $\mathrm{CO}$ content increased from $0.8 \mathrm{vol} \%$ to $1.2 \mathrm{vol} \%$ since NO degradation depended on the content and activity of catalyst in sinter zone, such as $\mathrm{Fe}-\mathrm{Ca}$ oxide.

\subsection{Reaction Behavior of NO in Combustion Zone}

\subsubsection{Effect of the Temperature of Combustion Zone}

In order to reveal the effect of NO in FGR gas on NO generation in different combustion zone, three combustion zone with different maximum temperature was set (their heat patterns were given in Fig. 6). Figure 7 shows the reaction behavior of NO in these three combustion zones. With the increase of the temperature of combustion zone, the burning velocity of fuel was increased as well as NOx content in outlet gas under the air condition. When 345 ppm NO existed in the gas atmosphere, the fuel combustion barely changed. However, the total NO emissions with the existence of 345 ppm NO were less than the sum of the NO

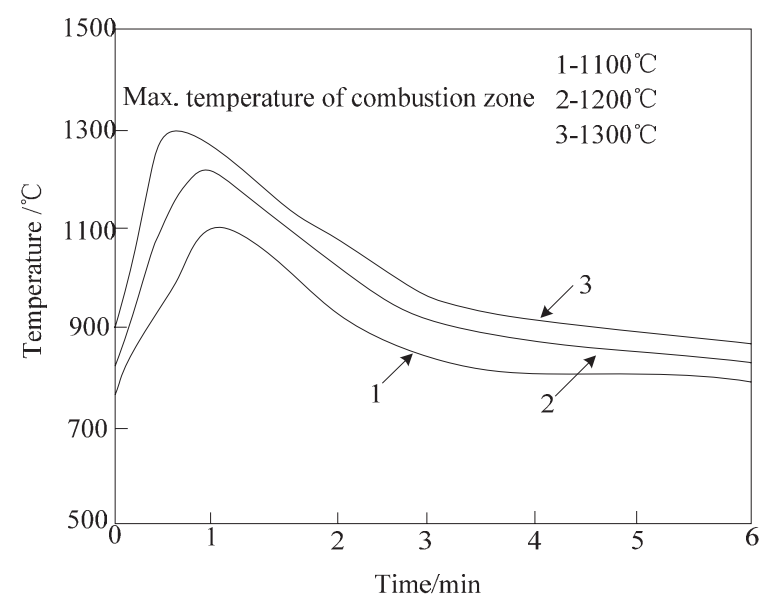

Fig. 6. Heat pattern of $25 \mathrm{~mm}$ distance away from the top of sample bed under different maximum temperature.

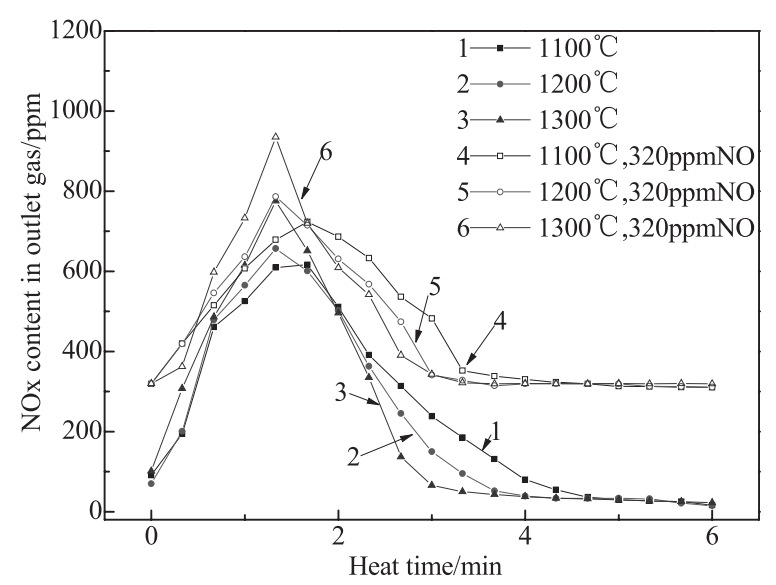

Fig. 7. Influence of temperature on reaction behavior of $\mathrm{NO}$ in combustion zone. generations under air condition and NO content of inlet gas. It means the existence of NO inhibits the NOx generation from fuel combustion; meanwhile, the $\mathrm{NO}$ elimination in NO-Carbon reaction is significant. Moreover, the NO-Carbon reaction is enhanced with the temperature increasing.

\subsubsection{Effect of Combustion Atmosphere}

Figure 8 shows the effect of $\mathrm{O}_{2}$ content in circulating flue gas on $\mathrm{COx}$ and $\mathrm{NOx}$ emissions at $1300^{\circ} \mathrm{C}$. With the decrease of $\mathrm{O}_{2}$ content in circulating flue gas, $\mathrm{CO}_{2}$ content in outlet gas reduced while $\mathrm{CO}$ content increased gradually. Meanwhile, the burning velocity decreased when $\mathrm{O}_{2}$ content decreased. It indicated that the decrease of $\mathrm{O}_{2}$ in circulating flue gas resulted in a decrease in the fuel combustion efficiency (combustion ratio $\mathrm{CO}_{2} /\left(\mathrm{CO}+\mathrm{CO}_{2}\right)$. At the same time, the total $\mathrm{NO}$ emissions and peak in outlet gas were both decreased gradually with the decrease of $\mathrm{O}_{2}$ in circulating flue gas.

The fuel combustion behavior is also affected with the presentence of $\mathrm{CO}_{2}$ as low $\mathrm{O}_{2}$ content in combustion zone. The oxygen content $\left(\mathrm{CO}_{2}+0.5 \mathrm{CO}+\mathrm{O}_{2}\right)$ in outlet combustion gas should be $21 \mathrm{vol} \%$ since there are no decarbonations, oxide reductions or air leakage in combustion tests. Figure 9 shows the effect of $\mathrm{CO}_{2}$ content in circulating flue gas on $\mathrm{NO}$ emissions of outlet gas. With the increase of $\mathrm{CO}_{2}$ content and decrease of $\mathrm{O}_{2}$ content, the burning velocity of coke deceased and NO content in outlet gas significantly reduced. NO content in outlet gas was decreased from 829 ppm to $649 \mathrm{ppm}$ when $\mathrm{CO}_{2}$ content in circulating flue gas increased from $0 \mathrm{vol} \%$ to $4 \mathrm{vol} \%$.

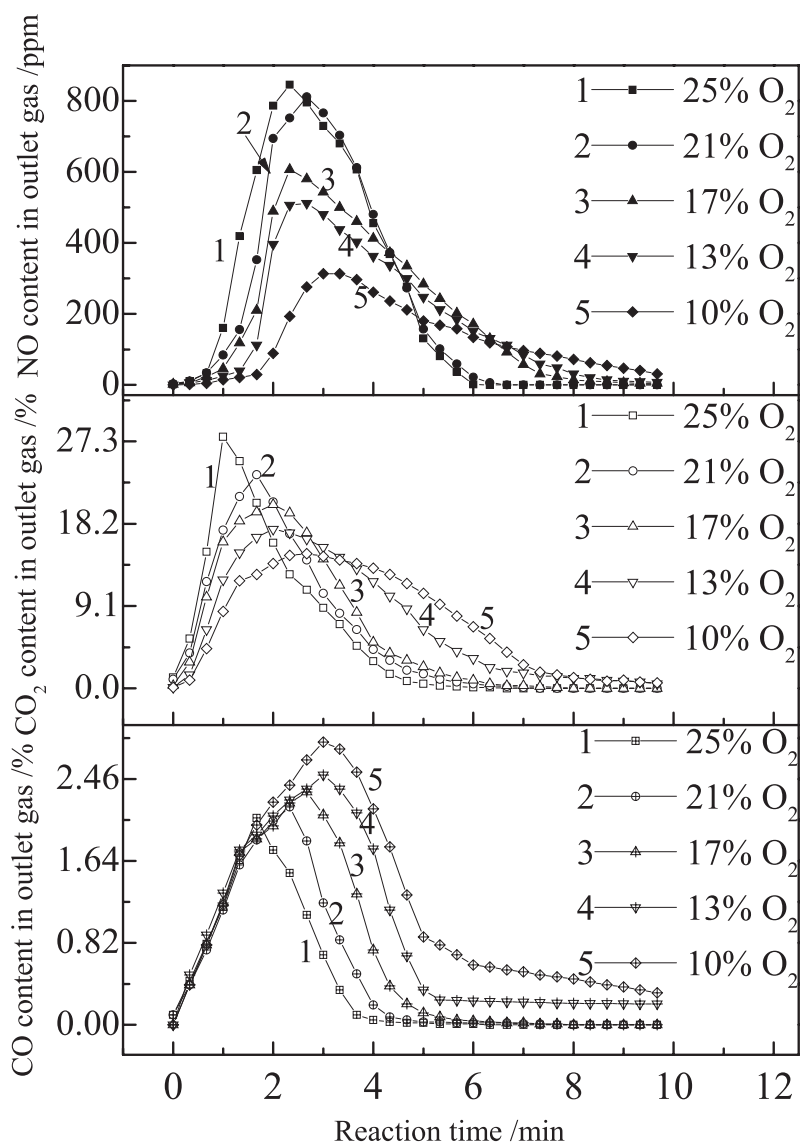

Fig. 8. Influences of $\mathrm{O}_{2}$ content on fuel combustion and $\mathrm{NOx}$ emission (under $1300^{\circ} \mathrm{C}$ ). 


\subsection{Effects of Flue Gas Recirculation on the NOx Reduction}

Table 5 shows the comparison of sinter indexes between convention and FGR. The sintering indexes were better than that of the conventional sintering in the case of FGR with less than $30 \mathrm{vol} \%$ recirculation ratio. However, they got significantly worse when FGR ratio increased to 35 $\mathrm{vol} \%$. The appropriate recirculation ratio should be better no more than $30 \mathrm{vol} \%$. With the increase of FGR ratio, the waste gas emissions reduced gradually. It had a very good implementation for exhaust gas emissions reduction under a higher FGR ratio; however, it results in a decrease in sintering indexes by the significantly reduced $\mathrm{O}_{2}$ content of the FGR gas. Thus, the sintering indexes and exhaust gas emissions reduction should be considered simultaneously in the application of FGR technology.

Figure 10 shows the flow diagram of sintering process with FGR, which is EOS-like lay out. The concept of this technique is to recycle a part of the mixed waste gas from

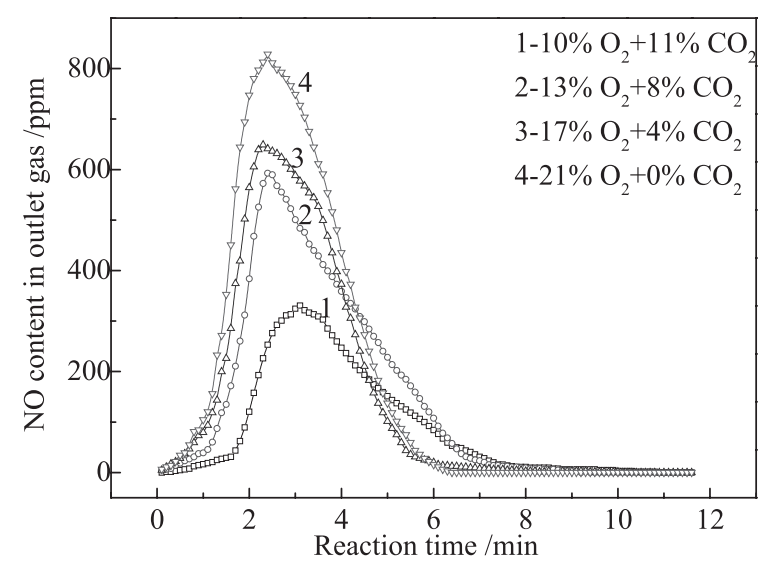

Fig. 9. Influences of $\mathrm{CO}_{2}$ content on fuel combustion (under $\left.1300^{\circ} \mathrm{C}\right)$.

Table 5. Comparison of sinter indexes between convention and FGR.

\begin{tabular}{cccccc}
\hline $\begin{array}{c}\text { Sintering } \\
\text { condition }\end{array}$ & $\begin{array}{c}\text { Recirculation } \\
\text { ratio/vol\% }\end{array}$ & $\begin{array}{c}V S V / \\
\mathrm{mm} \cdot \mathrm{min}^{-1}\end{array}$ & $Y / \%$ & $T I / \%$ & $P / \mathrm{t} \cdot \mathrm{m}^{-2} \cdot \mathrm{h}^{-1}$ \\
\hline Conventional & 0 & 26.67 & 69.24 & 52.70 & 1.69 \\
& 20 & 28.94 & 69.91 & 53.00 & 1.90 \\
FGR & 25 & 27.76 & 69.30 & 53.00 & 1.82 \\
& 30 & 26.76 & 68.20 & 51.75 & 1.70 \\
& 35 & 23.45 & 67.90 & 47.95 & 1.48 \\
\hline
\end{tabular}

the whole strand back to the entire surface of the strand. The FGR rate of the sintering waste gas is $30 \%$, corresponding to a $16.57 \mathrm{vol} \% \mathrm{O}_{2}, 2.87 \mathrm{vol} \% \mathrm{CO}_{2}, 0.28 \mathrm{vol} \% \mathrm{CO}, 3.96$ vol\% $\mathrm{H}_{2} \mathrm{O}(\mathrm{g})$ and $256 \mathrm{ppm} \mathrm{NO}$ in the wet gas/air mixture in the hood. The effects of FGR on the emissions reduction of NOx were shown in Table 6. Compared with the conventional sintering process, $30 \%$ reduction in gas flow was achieved in the case of $30 \mathrm{vol} \%$ FGR ratio. Otherwise, the nitrogen conversion rate of the FGR was $37.28 \%$, which was significantly lower than that of the conventional sintering process of $58.09 \%$. However, the NOx content in exhaust gas increased from $579 \mathrm{mg} / \mathrm{m}^{3}$ to $741 \mathrm{mg} / \mathrm{m}^{3}$, which leads to $10.91 \%$ reduction in the NOx emission.

\section{Discussions}

\subsection{Elimination Mechanism of NOx in Sinter Zone}

During the FGR process, NOx content in circulating flue gas will be reduced because of the existence of reduction agents in sinter zone, such as $\mathrm{CO}$. At the same time, $\mathrm{NO}$ and $\mathrm{CO}$ gas in circulating flue gas will be oxidized. The reaction behaviors of $\mathrm{NO}$ and $\mathrm{CO}$ in sinter zone mainly include the following equations:

$$
\begin{aligned}
& 2 \mathrm{NO}+\mathrm{O}_{2}=2 \mathrm{NO}_{2} \quad \Delta \mathrm{G}_{\mathrm{T}}=-162424+17.824 \mathrm{~T} \ldots \ldots \ldots . . \\
& 2 \mathrm{NO}+2 \mathrm{CO}=2 \mathrm{CO}_{2}+\mathrm{N}_{2} \quad \Delta \mathrm{G}_{\mathrm{T}}=-746510+624.88 \mathrm{~T}
\end{aligned}
$$

$2 \mathrm{CO}+\mathrm{O}_{2}=2 \mathrm{CO}_{2} \quad \Delta \mathrm{G}_{\mathrm{T}}=-565928+172.8 \mathrm{~T}$

Figure 11 shows the relationship of $\ln \mathrm{K}_{\mathrm{p}}-\mathrm{T}$. The $\ln _{\mathrm{p}}-\mathrm{T}$ curves of (R1), (R2) and (R3) with the increase of temperature. When the temperature increases from $500^{\circ} \mathrm{C}$ to $1100^{\circ} \mathrm{C}$, the $\ln \mathrm{K}_{\mathrm{R} 1}$ (reaction equilibrium constant of (R1)) varies from 24 to 10. It can explain the existence of $\mathrm{NO}_{2}$ in

Table 6. Effects of FGR on the emissions reduction of exhaust gas.

\begin{tabular}{lccc}
\hline \multicolumn{1}{c}{ Waste gas } & $\begin{array}{c}\text { Conventional } \\
\text { sintering }\end{array}$ & $\begin{array}{c}\text { FGR } \\
\text { sintering }\end{array}$ & $\begin{array}{c}\text { Reduction } \\
\text { rate } / \%\end{array}$ \\
\hline Flow $/ \mathrm{Nm}^{3}{ }_{\mathrm{dry}} \cdot \mathrm{h}^{-1}$ & 22.36 & 15.65 & 30.00 \\
Nitrogen conversion rate $/ \%$ & 58.09 & 37.28 & 35.82 \\
*NOx emission $/ \mathrm{mg} \cdot \mathrm{Nm}^{-3}$ & 579 & 741 & 10.91 \\
\hline
\end{tabular}

* Mass of NOx emission (mg) is calculated as $\mathrm{NO}_{2}$ Molecular mass (46 g/ mol).

Circulating gas via hood volume: $316.7 \mathrm{~m}^{3} / \mathrm{t}$ $\mathrm{O}_{2}$ content: $9.3 \%$

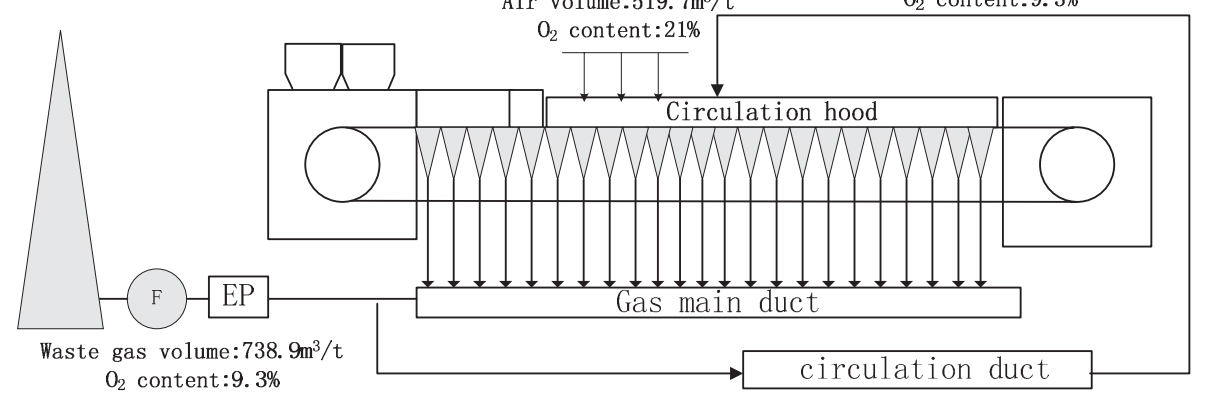

Waste gas recirculation system

Fig. 10. Flow diagram of sintering process with flue gas recirculation. 


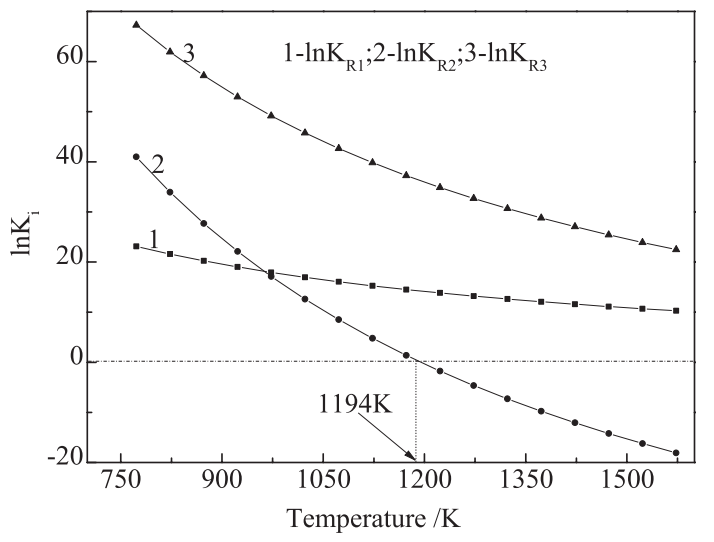

Fig. 11. $\operatorname{lnKp}$-T curve of reaction in sinter zone.

sinter zone and $\mathrm{NO}_{2}$ content decreased with the increase of sinter temperature. However, the $\ln K_{R 2}$ and $\ln K_{R 3}$ are significantly decreased with the temperature increasing. When the sinter temperature is higher than $1194 \mathrm{~K}\left(921^{\circ} \mathrm{C}\right)$, the $\mathrm{K}_{\mathrm{R} 2}$ performs as $\mathrm{K}_{\mathrm{R} 2}<1$. It means (R2) (the $\mathrm{NO}$ reduction reaction in sinter zone) almost does not exist when the temperature is higher than $921^{\circ} \mathrm{C}$ since the $\Delta \mathrm{G}$ of (R2) is greater than zero under this condition. However, the degree of (R3) reduces but the reaction (R3) direction doesn't change with the increase of sinter temperature since the $\mathrm{K}_{\mathrm{R} 3}>>1$.

The NO reduction at the surface of sinter contains two parts: one is $\mathrm{Fe}$ in sinter, which is produced by the reduction of $\mathrm{Fe}_{\mathrm{i}} \mathrm{O}_{\mathrm{j}}$ by $\mathrm{CO}$, acts as a reduction agent for deoxidizing $\mathrm{NO}$ to $\mathrm{N}_{2}$; the other is $\mathrm{NO}$ is deoxidized to $\mathrm{N}_{2}$ directly by $\mathrm{CO}$ with the catalysis of metal oxides in sinter. Figure 12 shows the influence of stuffing agents on $\mathrm{NO}-\mathrm{CO}$ reaction. According to the research result, an increase in NOx reduction rate occurred obviously with the increase of $\mathrm{CO}$ content in FGR gas over sinter agent. However, NO-CO reaction hardly conducted over silica or null agent even if $\mathrm{CO}$ content in FGR gas was $1.2 \mathrm{vol} \%$. Therefore, the sinter plays a role as catalysis of $\mathrm{NO}-\mathrm{CO}$ reaction during the FGR process.

\subsection{Elimination Mechanism of NOx in Combustion Zone}

NOx formations come from volatile-N and char-N oxidation in the fuel combustion process. However, $70 \%-90 \%$ nitrogen elements of fuel are separated out in volatiles over $1000^{\circ} \mathrm{C}$. The nitrogen-containing intermediates in the combustion of volatile- $\mathrm{N}$ include $\mathrm{NH}_{3}$ and $\mathrm{HCN}$, which participates in the NOx reduction homogeneously or heterogeneously. ${ }^{19,20)}$ The nitrogen in fuel will be split into nitrogen-containing intermediates $\left(\mathrm{NH}_{\mathrm{i}}\right.$ and $\left.\mathrm{HCN}\right)$ more under a low $\mathrm{O}_{2}$ partial pressure. At the same time, the NOx content in FGR gas will be decreased further because of the existence of reducing agents in sintering bed, such as $\mathrm{CO}$ and $\mathrm{C}$. The reaction in combustion zone mainly covered following equations besides (R1), (R2) and (R3), and the thermodynamic equations curves in combustion zone are shown in Fig. 13.

$$
\begin{array}{r}
2 \mathrm{NO}+2 \mathrm{C}=2 \mathrm{CO}+\mathrm{N}_{2} \quad \Delta \mathrm{G}_{\mathrm{T}}=-404664-153.764 \mathrm{~T} \ldots .(\mathrm{R} 4) \\
2 \mathrm{NO}+\mathrm{C}=\mathrm{CO}_{2}+\mathrm{N}_{2} \quad \Delta \mathrm{G}_{\mathrm{T}}=-574087+21.923 \mathrm{~T} \ldots . .(\mathrm{R} 5) \\
\mathrm{C}+\mathrm{O}_{2}=\mathrm{CO}_{2} \quad \Delta \mathrm{G}_{\mathrm{T}}=-394133-0.84 \mathrm{~T} \ldots \ldots . .(\mathrm{R} 6)
\end{array}
$$

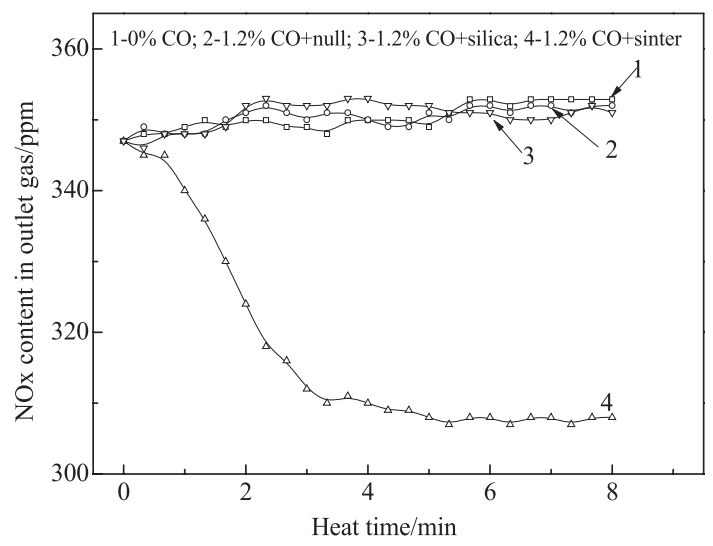

Fig. 12. Influence of stuffing agents on $\mathrm{NO}-\mathrm{CO}$ reaction.

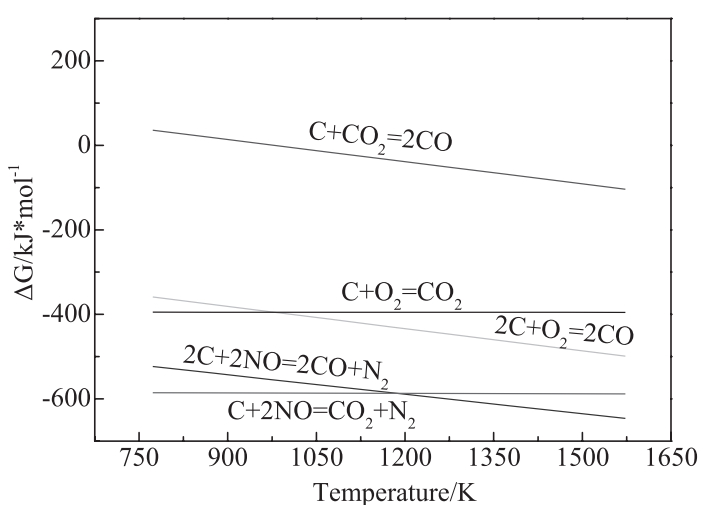

Fig. 13. Diagram of thermodynamic equations in combustion zone.

$$
\begin{aligned}
2 \mathrm{C}+\mathrm{O}_{2} & =2 \mathrm{CO} \quad \Delta \mathrm{G}_{\mathrm{T}}=-223426-175.31 \mathrm{~T} \ldots . \\
\mathrm{C}+\mathrm{CO}_{2}=2 \mathrm{CO} & \Delta \mathrm{G}_{\mathrm{T}}=-170707-174.47 \mathrm{~T} \ldots
\end{aligned}
$$

As observed from Fig. 13, the combustion behavior of coke in combustion zone mainly conducts as (R3), (R6), (R7) and (R8). (R6) plays the most important role in the coke combustion and it might be affected hardly by the temperature since the $\Delta \mathrm{G}^{0}-\mathrm{T}$ curve of (R6) is paralleled with coordinate axis. (R7) and (8) are easily found out in combustion zone over $1000^{\circ} \mathrm{C}$, which results in an increase in $\mathrm{CO}$ content. Moreover, much more $\mathrm{CO}$ will generate over fuel surface as the significantly reduced $\mathrm{O}_{2}$ and increased $\mathrm{CO}_{2}$ contents of FGR gas. It contributes to NOx elimination in $\mathrm{NO}-\mathrm{CO}$ reaction.

Besides NO-CO reaction, the NO-carbon reactions will be found out easily in combustion zone. The products of NO-carbon reaction are generally found to be $\mathrm{N}_{2}, \mathrm{CO}$ and $\mathrm{CO}_{2}$. The heterogeneous reactions of $\mathrm{NO}$ with carbon surface have been well recognized as the most important processes of reducing NO in the combustion zone. The NOcarbon reaction is made up of several processes. ${ }^{21)}$ The first step is the chemisorptions of $\mathrm{NO}$ on carbon which occurs along with the formation of carbon-oxygen complexes. $\mathrm{N}_{2}$ is the only product in this temperature range:

$$
2 \mathrm{NO}+2 \mathrm{C} \rightarrow 2 \mathrm{C}(\mathrm{O})+\mathrm{N}_{2}
$$

It has been suggested that the $\mathrm{O}$ atom of $\mathrm{NO}$ molecule is held to the surface, which means that NO is adsorbed in O-down orientation. The oxygen complexes were then postulated as the sites for physical adsorption. NO adsorption 


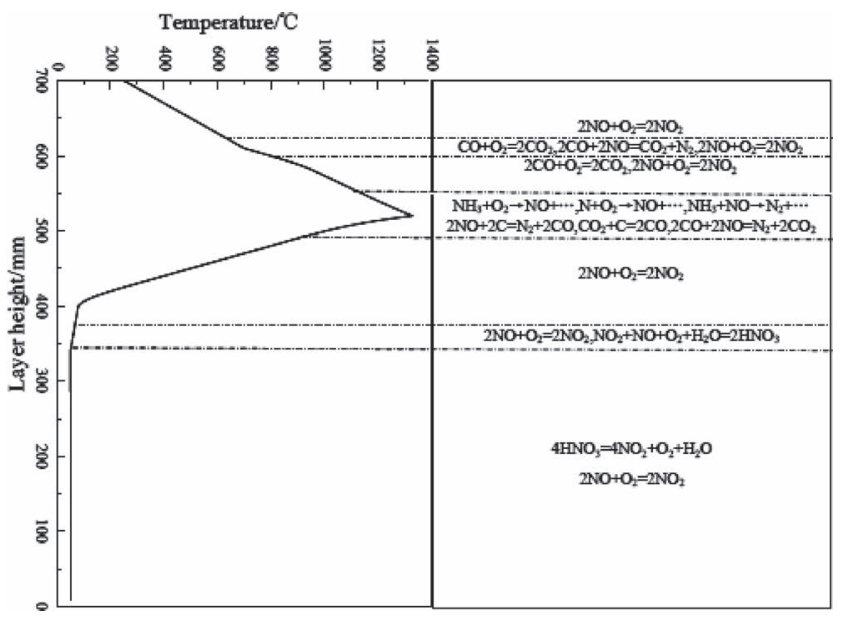

Fig. 14. Cross-section drawn of sintering pot.

also occurs in a N-down orientation to form N-containing complexes $\mathrm{C}(\mathrm{N})$. The reaction (R9), if applied to the higher temperature regime, could be split into two steps:

$$
\begin{aligned}
& \mathrm{NO}+2 \mathrm{C} \rightarrow \mathrm{C}(\mathrm{O}) \\
& 2 \mathrm{C}(\mathrm{N}) \rightarrow \mathrm{N}_{2}+2 \mathrm{C}
\end{aligned}
$$

Desorption of $\mathrm{C}(\mathrm{O})$ to form $\mathrm{CO}$ is an important step for all practical oxidizing carbon gasification processes, and must be present in the mechanistic model:

$$
\mathrm{C}(\mathrm{O}) \rightarrow \mathrm{CO}
$$

The route to $\mathrm{CO}_{2}$ formation was proposed to follows:

$$
\begin{aligned}
& \mathrm{C}+\mathrm{C}(\mathrm{O})+\mathrm{NO} \rightarrow \mathrm{C}\left(\mathrm{O}_{2}\right)+\mathrm{C}(\mathrm{N}) \\
& \mathrm{C}\left(\mathrm{O}_{2}\right) \rightarrow \mathrm{CO}_{2}
\end{aligned}
$$

\subsection{Behavior of NO in the Sintering Process}

Figure 14 shows reaction behaviors of NOx in each zone of sintering machine. As the above study preserved, $\mathrm{NO}$ of FGR gas is reduced to produce $\mathrm{N}_{2}$ in the way of $\mathrm{NO}-\mathrm{CO}$ reaction in sinter zone, meanwhile, it is also oxidized to form $\mathrm{NO}_{2}$. Most of $\mathrm{CO}$ of FGR gas takes post-combustion under a high temperature. The NOx formation supervenes with coke combustion in combustion zone. Almost all of fuel-N is decomposed to generate intermediate products, including $\mathrm{N}, \mathrm{CN}, \mathrm{HCN}$ and $\mathrm{NH}_{\mathrm{i}}$ compounds. On one hand, these intermediate products could be transformed to NO if there are some oxy-compounds like $\mathrm{O}, \mathrm{O}_{2}$ and $\mathrm{OH}$ etc. On the other hand, they can react with $\mathrm{NO}$ to form $\mathrm{N}_{2}$. The combustion atmosphere is the key point on the NOx elimination in combustion zone. Moreover, the NO-CO and NO-Carbon reactions conduct drastically in combustion zone, which contributes to the NOx elimination further.

\section{Conclusion}

(1) The flue gas recirculation sintering process is proposed based on part of flue gas is reused by reintroducing the flue gas into sintering bed, which is of great significance to cleaner production of sinter because it can reduce significantly the emission of exhaust gas as well as pollutants emission.

(2) The elimination behavior of NOx in sinter zone is in the way of NO-CO catalysis reaction, and the degradation rate of $\mathrm{NOx}$ reaches a maximum at $700^{\circ} \mathrm{C}$. The $\mathrm{NOx}$ formation supervenes with coke combustion in combustion zone. The NOx formation decreases due to the significantly reduced $\mathrm{O}_{2}$, increased $\mathrm{CO}_{2}$, and increased $\mathrm{NO}$ of FGR gas. The combustion atmosphere is the key point on the NOx elimination since the fuel-N decomposition intermediate products could transform to $\mathrm{NO}$ or reduce NO. Moreover, the NO-CO and NO-carbon reactions conducting in combustion zone contributes to the NOx elimination further.

(3) The elimination behavior of NOx during flue gas recirculation sintering process can propose the mechanism or operating parameters that how to reduce the NOx emission in sintering process which makes a contribution to the further NOx reduction of exhaust gas in FGR sintering.

\section{Acknowledgment}

The research is financially supported by National Natural Science Foundation of China (No.51304245), 2014 Hunan Provincial Innovation Foundation for Postgraduate (CX2014B094) and outstanding and creative doctor scholarship of Central South University (2013bjjxj015).

\section{REFERENCES}

1) J. N. Galloway, F. Dentener, D. Capone, C. Cleveland, P. Green, E. Holland, D. Karl, A. Michaels, J. Porter, A. Townsend and C. Vörösmarty: Biogeochemistry, 70 (2004), 153.

2) J. D. Felix, E.-M. Elliott and S.-L. Shaw: Environ. Sci. Technol., 46 (2012), 3528.

3) Y. N. Bai: Safety Environ. Eng., 2 (2006), 52 (in Chinese).

4) T. Y. Zhu: Technology of Sintering Flue gGas cleaning; Chemical Industry Press, Beijing, China, (2009), 1 (in Chinese).

5) L. L. Fang: Master Thesis. Shandong University, Jinan, Shandong Province, (2007), 13 (in Chinese).

6) Y. G. Chen, Z. Wang and Z. C. Guo: Acta Scientiae Circumstantiae, 28 (2008), 1720 (in Chinese).

7) C. G. Jin, H. G. Su and L. J. Nam: Korean Patent, 20020040506(A), 2002-05-30.

8) C. L. Mo, C. S. Teo, I. Hamilton and J. Morriso: ISIJ Int., 37 (1997), 350 .

9) K. Morioka, S. Inaba, M. Shimizu, K. Ano and T. Sugiyama: ISIJ Int., 40 (2000), 280.

10) X. G. Bi, J. Y. Liao, W. Xiong, G. F. Zhou and Z. H. Feng: J. Wuhan Univ. Sci. Technol., 5 (2008), 449 (in Chinese).

11) Y. G. Chen, Z. Wang and Z. C. Guo: Acta Scientiae Circumstantiae, 28 (2008), 1727 (in Chinese).

12) M. Gan: $\mathrm{PhD}$ Dissertation, Central South University, Changsha, Hunan Povince, (2012), 12 (in Chinese).

13) T. Terris and B. Hsiaotao: Environ. Sci. Technol., 43 (2009), 5049.

14) S. Ikehara, J. Sakuragi, S. Kubo and Y. Terada: Nippon Steel Tech. Rep. (Japan), 70 (1996), 55.

15) N. Menad, H. Tayibi, F. G. Carcedo and A. Hernandez: J. Ceaner Poduct., 14 (2006), 740.

16) A. Fleischander, C. Aichingerz and E. Zwitta: China Metall., 18 (2008), 41.

17) X. H. Fan, Z. Y. Yu, M. Gan, W. Q. Li and Z. Y. Ji: J. Iron Steel Res. Int., 20 (2013), 1.

18) E. Kasai, S. L. Wu, T. Sugiyama, S. Inaba and Y. Omori: Tetsu-toHagané, 78 (1992), 1005.

19) C. P. Finimore: Combust. Flame, 26 (1976), 249

20) M. Shelef: Cham. Rev., 95 (1995), 209.

21) K. Hauff, U. Tuttlies, G. Eigenberger and U. Nieken: Ind. Eng. Chem. Res., 52 (2013), 8399. 